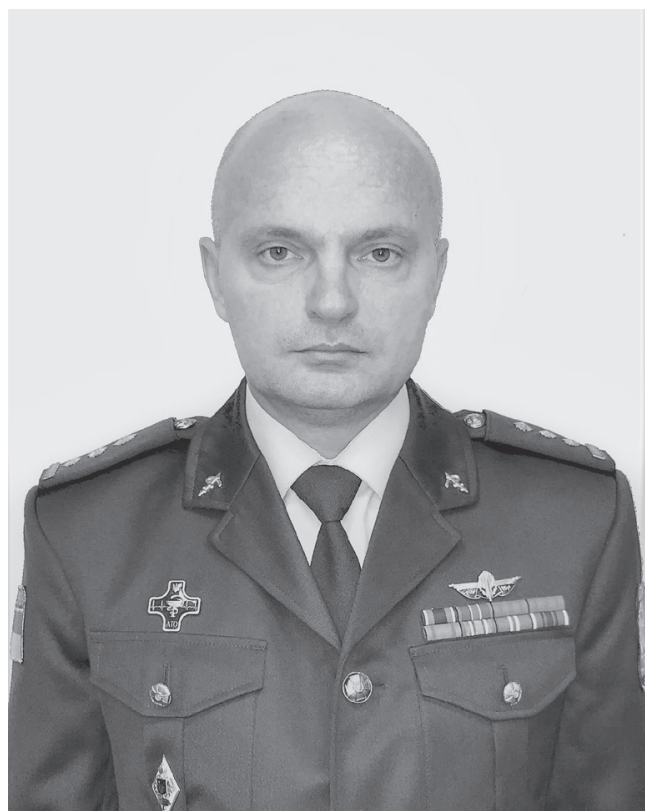

УДК: 351.7

DOI: https://doi.org/10.32689/2617-

2224-2019-18-3-44-58

Бакай Андрій Євгенович,

аспірант кафедри сочіальної $і$ гуманітарної політики Національної академіі державного управління при Президентові України, заступник начальника управління - начальник оперативно-медичного відділу управління охорони здоров'я, Адміністрачія Державної прикордонної служби України, 03057, м. Київ, вул. Антона Цедіка, 20, тел.: +38 06765253 68, e-mail: a.e.bakai@ukr.net

ORCID: 0000-0001-8752-2159

Бакай Андрей Евгеньевич,

аспирант кафедры сочиальной и гуманитарной политики Национальной академии государственного управления при Президенте Украины, заместитель начальника управления - начальник оперативномедичинского отдела управления здравоохранения, Администрачия Государственной пограничной службы Украины, 03057, г. Киев, ул. Антона Цедика, 20, тел.: +38 067652 53 68,e-mail:a.e.bakai@ukr.net

ORCID: 0000-0001-8752-2159

Bakai Andrii Evgenovich, postgraduate student National academy of public administration under President of Ukraine, Deputy Head of Department - Head of the Operational Medical Department of the Health Department, Administration of the State Border Service of Ukraine 03057, Kyiv, Str. Antona Tsedika, 20, tel.: +38 06765253 68, e-mail:a.e.bakai@ukr.net

ORCID: 0000-0001-8752-2159

\title{
АРХЕТИПНІ ДЖЕРЕЛА РОЗВИТКУ ДЕРЖАВНОЇ СИСТЕМИ МЕДИЧНОГО ЗАХИСТУ НАСЕЛЕННЯ УКРАЇНИ В НАДЗВИЧАЙНИХ СИТУАЦІЯХ
}

Анотація. Розглянуто архетипні джерела і нормативно-правові основи розвитку та функціонування державної системи медичного забезпечення і захисту населення України у надзвичайних ситуаціях, визначено сучасні проблеми та запропоновано нові підходи до організації публічного адміністрування медичним забезпеченням населення України у надзвичайних ситуаціях та реалізації потреби населення в медичному захисті при виникненні надзвичайних ситуацій у мирний і військовий час. 
Схарактеризовано основні форми організації системи охорони здоров’я у надзвичайних ситуаціях, проведено оцінку ключових проблем з організації медичного захисту (як системи заходів організаційно-управлінського характеру та їх реалізаціі), наголошено на доцільності об'єднання та спільного використання цивільно-військових органів та систем оперативного управління при подоланні наслідків надзвичайних ситуацій з використанням міжнародного досвіду в організації інтегрованої системи медичного забезпечення, що за певних умов дасть змогу досягнути сумісності з питань медичного забезпечення у спільних операціях з підтримання миру. Визначено поняття “медичне забезпечення" та "медичний захист", теоретично обгрунтувано необхідність структурно-організаційних трансформацій системи охорони здоров’я. Наголошено на подальшому розвитку загальної системи медичного забезпечення зі збереженням безпекової складової на засадах єдиного медичного простору та іiї інтеграції в загальнодержавну систему охорони здоров’я.

Проаналізовано існуючі моделі міжвідомчої кооперації з питань медичного забезпечення населення, розглянуто існуючі ограни управління медичним захистом населення та проектні форми міжвідомчої взаємодії у надзвичайних ситуаціях воєнного і мирного характеру, підтверджено доцільність удосконалення механізмів міжвідомчої взаємодії з організації медичної допомоги постраждалим у надзвичайних ситуаціях.

Визначено основні передумови побудови солідарного медичного простору відомчих медичних служб та цивільної системи охорони здоров’я, що зумовлює необхідність централізації механізмів управління медичним захистом населення, визначення та впровадження єдиних принципів організації медичної допомоги, розроблення і реалізації нових стратегій та програм міжсекторальної та міжвідомчої взаємодії.

Ключові слова: архетипні джерела системного розвитку, медичне забезпечення, управління медичним захистом.

\section{АРХЕТИПНЫЕ ИСТОЧНИКИ РАЗВИТИЯ ГОСУДАРСТВЕННОЙ СИСТЕМЫ МЕДИЦИНСКОЙ ЗАЩИТЫ НАСЕЛЕНИЯ УКРАИНЫ В ЧРЕЗВЫЧАЙНЫХ СИТУАЦИЯХ}

Аннотация. Рассмотрены архетипные источники и нормативно-правовые основы функционирования государственной системы медицинского обеспечения и защиты населения Украины в чрезвычайных ситуациях, охарактеризованы современные проблемы и предложены новые подходы в организации публичного администрирования медицинским обеспечением населения Украины в чрезвычайных ситуациях и реализации потребности населения в медицинской защите при возникновении чрезвычайных ситуаций в мирное и военное время.

Охарактеризованы основные формы организации системы здравоохранения в чрезвычайных ситуациях, проведена оценка ключевых проблем в организации медицинской защиты (как системы мер организационно-управ- 
ленческого характера и их реализации), акцентировано внимание на целесообразности объединения и совместного использования военно-гражданских органов и систем оперативного управления при ликвидации последствий чрезвычайных ситуаций с использованием международного опыта в организации интегрированной системы медицинского обеспечения, что при определенных условиях позволит достичь совместимости в вопросах медицинского обеспечения в общих операциях по поддержанию мира. Определено понятие “медицинское обеспечение” и “медицинская защита”, теоретически обоснована необходимость структурно-организационных трансформаций в системе здравоохранения. Отмечена необходимость дальнейшего развития общей системы медицинского обеспечения с сохранением безопасности составляющей на основе единого медицинского пространства и ее интеграции в общегосударственную систему здравоохранения.

Проанализированы модели межведомственной кооперации в вопросах медицинского обеспечения населения, рассмотрены существующие органы управления медицинской защитой населения и проектные формы межведомственного взаимодействия в чрезвычайных ситуациях военного и мирного характера, подтверждена целесообразность усовершенствования механизмов межведомственного взаимодействия в организации медицинской помощи пострадавшим в чрезвычайных ситуациях.

Определены основные предпосылки построения солидарного медицинского пространства ведомственных медицинских служб и гражданской системы здравоохранения, что обусловливает необходимость централизации механизмов управления медицинской защитой населения, определения и внедрения единых принципов организации медицинской помощи, разработки и реализации новых стратегий и программ межсекторального и межведомственного взаимодействия.

Ключевые слова: архетипичные источники системного развития, медицинское обеспечение, управление медицинской защитой.

\title{
ARCHETYPICS OF SOURCE OF DEVELOPMENT OF THE STATE SYSTEM OF MEDICAL DEFENCE OF POPULATION OF UKRAINE IN EMERGENCIES
}

\begin{abstract}
The article discusses the archetypical sources and regulatory framework for the functioning of the state system of medical support and protection of the population of Ukraine in emergency situations, describes modern problems and suggests new approaches in organizing public administration of medical support for the population of Ukraine in emergency situations and meeting the needs of the population in medical protection emergency situations of peacetime and wartime.

The main forms of organization of the health care system in emergency situations were characterized, the key problems in the organization of medical protection were evaluated (as a system of organizational and managerial measures and their implementation), attention was paid to the expediency of combining
\end{abstract}


and sharing civil-military bodies and operational management systems in the aftermath emergency situations using international experience in organizing an integrated system of medical care, that, under certain conditions, will allow to achieve compatibility in matters of medical support in joint peacekeeping operations, defined the concept of "medical care" and "medical protection", conducted a theoretical justification of the need for structural and organizational transformations in the health care system. The necessity of further development of the general medical care system with preservation of the security component on the basis of a single medical space and its integration into the national health care system was noted.

Analyzed models of interdepartmental cooperation in matters of medical support of the population, reviewed the existing bodies of management of medical protection of the population and design forms of interdepartmental cooperation in emergency situations of a military and peaceful nature, confirmed the feasibility of improving the mechanisms of interdepartmental interaction in organizing medical assistance to victims in emergency situations.

The main prerequisites for building a joint medical space of departmental medical services and the civil health system are identified, which necessitates the centralization of the mechanisms for managing medical protection of the population, defining and introducing common principles for organizing medical care, developing and implementing new strategies and programs for interagency and interagency cooperation.

Keywords: archetypical sources of systemic development, medical support, management of medical protection.

“Шлях до сутності явища лежить через його визначення”. Аристотель

Постановка проблеми. У комплексі важливих проблем національної безпеки (національної політики України) питання ефективного управління, реформування та створення нових систем галузевого адміністрування у наші дні посідають чільне місце. Трансформаційні процеси, що відбуваються в Україні, поширюють свій вплив на всі сфери суспільного життя. Більшість проблемних питань в організації медичного захисту населення в загальнодержавній системі медичного забезпечення є комп- лексними, а механізми їх подолання знаходяться поза рамками можливості самостійної реалізації в рамках самої системи. Сприйняття та усвідомлення сутності та необхідності системних перетворень сприятиме прискоренню процесу реформування профільної галузі охорони здоров'я та оптимізації механізмів регуляції можливих трансформацій, що є основою розвитку сучасної цивілізації, суспільства, людини тощо.

Не викликає сумніву той факт, що взаємодія органів державної влади є 
визначальним елементом у міжсекторальних відносинах з організації надання медичної допомоги населенню. Наприклад, медичні служби військових формувань використовують наявні сили, ресурси та навички з метою забезпечення медичного захисту населення в загальній системі цивільно-військової взаємодії в надзвичайних ситуаціях воєнного та мирного часу, хоча це і не $є$ їх основною оперативною функцією.

У таких ситуаціях організація взаємодії між громадськими та військовими організаціями є ключовим питанням. Створення ефективних комунікативних зв'язків між суб'єктами публічного адміністрування, міжвідомче погодження практичних дій та чітка реалізація спільної думки дозволить на державному рівні виконувати сумісні інфраструктурні проекти, інвестувати профільну галузь та, в підсумку, створити єдиний оперативно-медичний простір України.

Значусті набуває і питання нормативно-правового врегулювання функціонування системи медичного забезпечення під час дії особливого періоду, надзвичайного стану, інших кризових ситуацій в Україні.

За таких обставин існуюча форма організації системи охорони здоров’я потребує ідентифікації та визначення стратегій (можливих сценаріїв) реагування та організації медичного захисту населення під час надзвичайних ситуацій та визначення дієвого механізму міжвідомчої кооперації як інструменту публічного управління медичним забезпеченням населення України.

Потребують визначення та актуалізації принципи і політика органі- зації медичного забезпечення сил оборони України в загальній системі охорони здоров'я, обгрунтування необхідності створення та існування єдиного медичного простору держави як інструменту системних змін в управлінні профільною галуззю та визначення порядку цивільно-військової взаємодії з питань надання медичної допомоги в надзвичайних ситуаціях населенню України (за солідарним принципом), розробки та впровадження загальновизнаної стратегії розвитку системи медичного забезпечення сил оборони з досягненням стратегічної мети “Ціль партнерства Україна - HATO G5404 "Реформування системи медичного забезпечення” та виконання кроків (індикаторів) плану пріоритетних дій Уряду в сфері обороноздатності та безпеки України.

Актуальність теми підтверджена гібридними викликами, які створюють відчутні медико-соціальні наслідки і продовжують чинити негативний вплив у теперішньому часі та віддаленому майбутньому та полягає в тому, що проблема надання медичної допомоги в надзвичайних ситуаціях під час надзвичайного стану та інших кризових ситуацій має багатоаспектний і комплексний характер, що зумовлює необхідність централізації механізмів управління системою медичного захисту, визначення та впровадження єдиних принципів організації медичної допомоги, розроблення і реалізації нових стратегій і програм міжсекторальної та міжвідомчої взаємодії, в тому числі програм медичної підготовки, функціональної інтеграції відомчих структур охорони здоров'я 
всіх форм власності, застосовування єдиних стандартів (нормативів) на загальних принципах тощо.

Аналіз останніх публікацій за проблематикою та визначення невирішених раніше частин загальної проблеми. Концептуальні засади взаємодії політики та управління, соціальної глобалістики, соціальних проблем становлення Збройних сил України започатковувались та закладались засновником наукових шкіл військово-соціальних досліджень, соціальної глобалістики та архетипіки публічного управління професором Е. А. Афоніним [1-4]. Визначенню теоретичних засад соціальної архетипіки присвячена низка робіт О. В. Суший [2; 4-6].

Питання державного управління медичним захистом у надзвичайних ситуаціях досліджували П. Волянський [7], С. Гур'єв [8], Н. Гуселєтова, Л. Жукова, О. Мостипан, А. Терентьєва.

Можливі механізми міжвідомчої координації зусиль із формування єдиного медичного простору при подоланні медико-санітарних наслідків надзвичайних ситуацій та планування медико-санітарного забезпечення населення на локальному рівні досліджували Н. Загоруйко, Н. Іскра, Р. Майданчик, О. Мельник, І. Слічко, В. Тарасюк. Можливість цивільно-військового співробітництва в загальній системі управління при подоланні наслідків надзвичайних ситуацій вивчали П. Кліменко, О. Мазуренко, О. Набоченко, Я. Радиш, А. Стойка, а також розглядали механізми міжсекторальної взаємодії органів державної влади і громадських об'єднань на регіональному рівні.
Досвід медичного забезпечення військ НАТО в організації медичного захисту персоналу та населення у надзвичайних ситуаціях розглянуто в статтях М. І. Бадюка, А. В. Баровської, В. О. Жаховського [9], О. Г. Шекери.

Характеризуючи загальний стан дослідження системи державного управління медичним захистом населення в надзвичайних ситуаціях воєнного і мирного часу, необхідно зазначити, що переважна більшість наукових праць розкривають виключно питання вузькопрофільного внутрівідомчого забезпечення (В. Білий, А. Верба, В. Лівінський, Г. Рощін) та не враховують необхідність “комплексного підходу в дослідженні соціальних і гуманітарних проблем воєнної організації, що здійснюється на міждисциплінарній основі та на умовах міжнародної кооперації" (Е. А. Афонін) [3].

Мета статті: дослідження принципів організації системи медичного забезпечення та цивільно-військової взаємодії у надзвичайних ситуаціях воєнного і мирного часу в частині модернізації системи управління медичним захистом та практичних дій щодо подолання проблем медичного забезпечення у різні періоди, а також визначення напрямів і шляхів його вдосконалення.

Виклад основного матеріалу дослідження. Дедалі частіше поняття “здоров'я нації” визнається як ключовий фактор стабільності та розвитку держави і суспільства. Великого значення набувають питання функціонування системи медичного забезпечення населення України за різних оперативних умов в особли- 
вому періоді, надзвичайному стані та інших кризових ситуаціях.

Кожна сфера соціального життя має свою логіку та ритм розгортання циклів, будь-який може бути незакінченим чи перериватися як через зовнішні історичні, так й іманентні стосовно суб’єкта обставини [4]. У процесі суспільної трансформації кардинальні зміни відбуваються не лише на зовнішньому - соціально-інституційному рівні суспільної системи, а й в глибинних структурах буття людей [5]. Українська Революція Гідності та військово-політичний конфлікт на Сході країни не лише змінили роль держави в сучасному світі, а й показали західному світові силу та незламність українського духу. Британський історик А. Тойнбі слушно зазначив: “Фізично матеріальне майбутнє мало залежить від нас. Землетрус може зруйнувати наш дім. Хай руйнується каміння, але світло, яке осяює наш шлях, не згасає. Зрештою, буде те, що має бути. Навіть якщо буде інакше” [5].

Необхідність оптимізації та модернізації процесів соціальної взаємодії, безумовно, передбачає опору на базові філософські і наукові традиції, що розкривають сутність організаційного простору життя людини. Досвід конфліктного століття наочно демонструє, що низка найпотужніших соціальних криз супроводжується небаченою раніше свободою у виборі теоретико-методологічних інтерпретацій в дослідженнях архетипів колективного несвідомого в становленні всіх форм соціальних відносин та взаємодії (по К. Г. Юнгу). Оскільки елементи в явній формі завжди знаходяться в резонансі з їх неявними і не представленими джерелами (які можна розглядати як “архетипні”, по К. Г. Юнгу), тож коли налаштована відповідним чином подія відбувається на рівні явного, це впливає і на неявний порядок, тобто на архетипне поле.

Трансформаційні процеси, що відбуваються в Україні, поширюють свій вплив на всі сфери суспільного життя [6]. У зв’язку зі зміною суспільно-політичного вектора виникла об'єктивна необхідність адаптації принципів і політики організації медичної допомоги в надзвичайних ситуаціях до міжнародних доктринальних стандартів, що зумовило необхідність наукового пошуку шляхів виконання цих завдань з урахуванням багатоукладності складових організації системи охорони здоров’я в Україні.

Своєю чергою, позаблоковий статус України не забезпечив захист держави від агресивної зовнішньої політики. Зважаючи на те, що міжнародні зобов'язання стосовно незалежності, суверенітету і недоторканності кордонів України виявилися нездатними гарантувати зовнішню безпеку, виникла потреба в докорінних змінах та формуванні нових принципів державної політики в сфері національної безпеки. Керуючись цілями та завданнями зовнішньої політики України та пріоритетами стратегічного партнерства, вважаємо за доцільне звернутися передусім до досвіду організації медичного забезпечення військово-політичного союзу "Організація Північноатлантичного договору” (НАТО) 3 метою застосування комунікативних інструментів міжнародного співро- 
бітництва та їх подальшого використання у сфері медичного захисту населення. Тобто практична цінність співробітництва у межах Урядових програм співробітництва Україна НАТО полягатиме, на нашу думку, в можливому використанні міжнародного досвіду при побудові власної моделі реагування на надзвичайні ситуації (організації системи медичного забезпечення в кризових ситуаціях).

У 2014 році Е. А. Афонін стверджував, що "на сегодняшний день, к сожалению, не удалось обнаружить ни одного комплексного исследования социальных и гуманитарных проблем военной организации, осуществленных на междисциплинарной основе и на условиях международной кооперации, хотя необходимость в таких исследованиях очевидна" [3].

Водночас подолання наслідків надзвичайних ситуацій завжди потребувало організації багаторівневої системи управління. Гармонізація нормативно-правових актів національного законодавства 3 положеннями директив Європейського Співтовариства та Європейським Союзом (ратифіковано Верховною Радою України у 2014 році) передбачає розроблення нового положення про Державну службу медицини катастроф, іiї структури та завдань, порядку взаємодії 3 державними структурами та громадськими об'єднаннями з надання екстреної медичної допомоги постраждалим у надзвичайних ситуаціях.

Публічне управління щодо надання медичної допомоги постраждалим в надзвичайній ситуації повин- но стати інтегрованою сукупністю заходів законодавчого, виконавчого і контрольного характеру, що здійснюється державними органами у сфері медичного захисту населення як складової єдиної державної системи цивільного захисту [1].

Варто акцентувати увагу, що в 2007 році міжнародними організаціями, такими як Бюро координації гуманітарних справ ООН, Всесвітньою Організацією охорони здоров’я, Міжнародною федерацією Червоного Хреста, НАТО тощо, було розроблено концепцію та основні принципи використання цивільного і військового компонентів при подоланні наслідків надзвичайних ситуацій, які отримали назву "Керівні принципи використання Збройних сил та Сил цивільного захисту" [10]. При цьому координацію дій при подоланні наслідків надзвичайних ситуацій запропоновано реалізовувати через розробку спільних планів подолання наслідків надзвичайних ситуацій та взаємодії і організації інформаційно-аналітичної підтримки за стандартними формами $\mathrm{OOH}$ i HATO.

У літературі розрізняють поняття медичного забезпечення і медичного захисту населення та військових контингентів, визначаючи медичне забезпечення як систему заходів щодо збереження та зміцнення здоров'я, запобігання виникненню та розповсюдженню хвороб, надання медичної допомоги, лікування та відновлення працездатності після поранень (захворювань). Поняття включає організаційні, лікувальноевакуаційні, санітарно-гігієнічні та протиепідемічні заходи, медичне по- 
стачання, підготовку військово-медичних кадрів i наукове вирішення проблем військової медицини. Реалізація зазначених заходів забезпечується наявністю відповідної нормативно-правової бази, відповідним матеріально-технічним забезпеченням, чіткою системою управління та інформаційною підтримкою.

На відміну, медичний захист - це комплекс адміністративно-правових, організаційних, планувальних та практичних заходів, спрямованих на запобігання або зменшення ступеня ураження людей внаслідок надзвичайної ситуації, своєчасного надання їм екстреної медичної допомоги та забезпечення санітарно-епідемічного благополуччя. Медичний захист населення включає застосування сил та засобів закладів охорони здоров'я незалежно від форми власності [12]. Однією з найважливіших складових цього процесу вбачається організація та міжвідомча координація процесу управління.

Аналіз стану законодавчо-нормативної бази 3 питань медичного захисту населення України в надзвичайних ситуаціях та під час особливого періоду свідчить про недосконалість інструментів взаємодії у єдиному медичному простоpi держави. Основним недоліком нормативно-правового регулювання медичного забезпечення населення у надзвичайних ситуаціях $є$ відсутність визначеного механізму приведення організаційно-штатної структури медицини катастроф до функціонування у державній системі медичного захисту населення. Порядок переводу формувань Державної служби медицини катастроф до роботи за умов надзвичайних ситуацій особливого періоду також не визначено [8]. Водночас відповідальність за організацію своєчасних і послідовно проведених заходів щодо надання адекватної медичної допомоги і лікування постраждалих покладена на органи влади постраждалих територій.

Організаційною складовою державної системи охорони здоров'я в надзвичайних ситуаціях в Україні є Служба медицини катастроф як особливий вид регіональної спеціалізованої аварійно-рятувальної медичної служби Центру екстреної медичної допомоги та медицини катастроф, основним завданням якої є надання безоплатної медичної допомоги постраждалому населенню в районі надзвичайної ситуації та під час евакуації до лікувальних закладів у повсякденний період та за умов особливого періоду. Медичні формування Державної служби медицини катастроф розгортаються на шляхах евакуації постраждалих, забезпечують ix прийом i надання гарантованого державою рівня медичної допомоги, тобто організовують і надають екстрену медичну допомогу на догоспітальному етапі, первинну та вторинну (з елементами спеціалізованої) медичну допомогу постраждалим при виникненні надзвичайної ситуаціï регіонального і державного рівнів (за ознаками розміру санітарних втрат). Отже, медичне забезпечення надзвичайних ситуацій здійснюється силами і засобами центрального та територіального рівнів, незалежно від відомчого підпорядкування.

Варто акцентувати увагу, що на сьогоднішній день служба медици- 
ни катастроф, як Державна служба, є підсистемою Державного цивільного захисту, що розбудована на центральному та регіональному рівнях. Централізація структури зумовлена необхідністю централізації управління при надзвичайній події державного рівня всіма силами Цивільного захисту, включаючи сили і засоби медичного захисту, з можливістю формування та доставки логістичних ресурсів, з обмеженням за часом.

Тобто державне управління щодо надання медичної допомоги постраждалим під час дії особливого періоду, надзвичайного стану, інших кризових ситуацій на сьогоднішній день є інтегрованою сукупністю методів державного управління, які передбачають систему заходів законодавчого, виконавчого і контрольного характеру, що здійснюється державними органами у сфері медичного захисту населення. У цьому контексті необхідним є визначення механізмів взаємодії органів публічного управління при організації медичного захисту населення. Відповідно, при здійсненні комплексу заходів під час дії особливого періоду, надзвичайного стану, інших кризових ситуацій виникає складність в організації взаємодії між усіма задіяними суб'єктами та контролі за виконанням їх функціональних обов'язків, що, в підсумку, впливає на оперативність реагування та ефективність управління [11].

Варто акцентувати увагу, що питання реорганізації системи сил та засобів медицини катастроф та медичного захисту населення під час дії особливого періоду, надзвичайного стану, інших кризових ситуа- цій відповідними державними органами (у тому числі за нормотворчу діяльність) безпідставно відкладаються. Втрата чинності цілої низки фундаментальних Законів України “Про Цивільну оборону України” (1993 р.), “Про аварійно-рятувальні служби” (1999р.), “Про захист населення і території від надзвичайних ситуацій технічного та природного характеру” (2000р.) призвела до невиконання вимог статей прямої діï цих законів. Також у зв’язку 3 прорахунками в системі державного нормативно-правового регулювання функціонування служби медицини катастроф (на сучасному етапі реформування системи медичного захисту населення України) нормативні акти прямої дії, які не відмінені органом управління, що його затвердив, за загальною юридичною практикою вважаються чинними та підлягають безумовному виконанню [8].

Нормативно-правову основу функціонування системи медичного забезпечення населення у надзвичайних ситуаціях в Україні формують Конституція України та Закон України “Основи законодавства України про охорону здоров’я”. Чинними відповідно до вимог правового поля є Закон України “Про екстрену медичну допомогу” [13] та, частково, вимоги Закону України “Кодекс цивільного захисту України” [12], які визначають організаційно-правові засади забезпечення громадян України та інших осіб, що перебувають на ii території, екстреною медичною допомогою, у тому числі під час виникнення надзвичайних ситуацій та ліквідації їх наслідків, та засади 
створення, функціонування i розвитку системи екстреної медичної допомоги [13].

Водночас за умов виникнення військової загрози потрібно враховувати обсяг, сили та ресурси, доступність та прийнятні стандарти військової і цивільної систем охорони здоров'я. Таким чином, на початковому етапі організації медичного забезпечення при виникненні надзвичайної ситуації воєнного часу медичні служби сил оборони України мають бути готовими надавати допомогу не лише пораненим військовослужбовцям, а й пораненим та хворим цивільним особам. Сили та ресурси військової системи охорони здоров'я можуть бути обмежені, а рівень потреб цивільного населення може бути важко підрахувати. Також слід розуміти, що надання безпосередньої медичної допомоги військовослужбовцям під час участі в територіальній обороні та відсічі збройної агресії можуть серйозно послабити місцеві сили та ресурси охорони здоров’я.

Здатність військових сил розгортати медичні ресурси в короткий термін за любих оперативних умов, з використанням спеціалізованої інфраструктури та наявною злагодженою системою управління, робить їх винятково дієвими. За таких умов організація взаємодії між військовими та цивільними силами і засобами охорони здоров'я є ключовим питанням.

Таким чином, з метою приведення відповідно до питань нормативно-правового регулювання у системі медичного забезпечення населення у надзвичайних ситуаціях в Україні має бути завершеним перегляд функ- цій та завдань органів та підрозділів, що формують та забезпечують політику медичного захисту населення, 3 метою уникнення дублювання відомчих систем управління, розподілі обов'язків керівників та підпорядкованих їм органів управління, з відображенням завдань середньострокового планування у стратегічних та оперативних програмах розвитку із зазначенням конкретних термінів виконання.

Широкий спектр гібридних викликів і загроз національним інтересам України зумовлює необхідність у виваженій державній воєнній політиці і дієвій стратегії у сфері реформування та розвитку Збройних сил України та правоохоронних органів - суб'єктів національної безпеки. Однією з основних цілей Стратегії національної безпеки України визначено утвердження прав і свобод людини та громадянина, забезпечення нової якості економічного, соціального і гуманітарного розвитку, інтеграції України до Свропейського союзу та формування умов для вступу в НАТО [14]. Одним із шляхів формування національних оборонних спроможностей визначено й модернізацію військової охорони здоров'я з концентрацією зусиль на заходах медичного забезпечення у можливих конфліктах та максимальною цивільно-військовою взаємодією у сфері охорони здоров’я. Розбудова демократичного суспільства на основі європейських цінностей підвищує вимоги до стану охорони здоров’я населення України в сучасних умовах. Громадський контроль над військовими структурами забезпечує дотримання законодавства 3 
питань соціального захисту військовослужбовців, насамперед, його медичної складової.

На нашу думку, головною причиною неадекватності системи медичного забезпечення в умовах гібридних загроз є відсутність базових нормативно-правових актів, які визначали б теоретичне підгрунтя організації системи підготовки цивільної і військової охорони здоров'я до роботи в надзвичайних ситуаціях та механізми організації медичного забезпечення військовослужбовців i цивільного населення у воєнний час. Реалізація положень Воєнно-медичної доктрини України та державної цільової програми iï виконання забезпечить створення сучасної стійкої та ефективної системи військової охорони здоров'я, яка стане повноцінною складовою національної системи охорони здоров'я на платформі єдиного медичного простору держави [9].

Застосування військових формувань у сучасних умовах проходить у складному безпековому середовищі. Війська можуть залучатись не лише для виконання бойових завдань, а й для відновлення інфраструктури як в Україні, так і за її межами, в тому числі для надання медичної допомоги цивільному населенню. Тобто система медичного забезпечення сил оборони здебільшого інтегрується із системою охорони здоров'я цивільного населення [8].

Цивільно-військову кооперацію з питань медичного забезпечення пропонується здійснювати за рахунок впровадження системи загального управління, координації, взаємодії, інформаційної підтримки, що перед- бачає спільне планування. Міністерство охорони здоров'я України відповідно забезпечує готовність закладів охорони здоров'я, інших необхідних сил та засобів щодо надання медичної допомоги під час дій особливого періоду, надзвичайного стану, а також різних кризових ситуацій.

Системні зміни світової та регіональної безпеки призвели до нових загроз суверенітету та територіальної цілісності України, які можуть бути реалізовані за різними сценаріями - від збройного конфлікту на державному кордоні до повномасштабної збройної агресії, що вимагає від системи військово-медичного забезпечення бути в постійній готовності та спроможною до медичного забезпечення не тільки військових контингентів, а й цивільного населення за різними варіантами їі застосування як самостійно, так і у взаємодії з цивільною системою охорони здоров'я, що зумовлює необхідність прийняття та затвердження єдиних принципів і політики медичного забезпечення.

Принципи і політика медичного забезпечення - це сукупність принципів, положень і єдиних організаційних вимог щодо порядку медичного забезпечення сил усіх складових сил оборони під час виконання завдань з оборони держави шляхом забезпечення на національному рівні міжвідомчої координації діяльності медичних служб відомчого підпорядкування і цивільної системи охорони здоров'я з метою ефективного та раціонального використання медичних ресурсів, забезпечення стандартизації надання медичної допомоги в надзвичайних 
ситуаціях, проведення евакуації, реабілітації через побудову системи медичного забезпечення за єдиними принципами. Правовою основою їх розроблення є закони України та інші нормативно-правові акти з питань оборони держави і охорони здоров'я. Принципи і політика відображають систему поглядів, керівні принципи, положення та вимоги щодо організації медичного забезпечення i не деталізують окремі його складові та клінічні аспекти.

Водночас інтеграція військової системи медичного забезпечення в єдиний медичний простір передбачає функціональне поєднання сил і засобів медичних служб сил оборони та системи охорони здоров'я цивільного населення з метою максимальної реалізації спроможностей зі збереженням організаційної самостійності.

Висновки і перспективи подальших досліджень. На основі аналізу можна зробити висновки, що ефективне функціонування державної системи медичного захисту населення у надзвичайних ситуаціях воєнного і мирного часу можливе за умов визначення єдиних принципів і політики та порядку організації взаємодії між координаційними органами управління.

За умов функціонального об'єднання органів управління та запровадження горизонтальних управлінських зв'язків медичні служби набувають спроможностей надавати допомогу постраждалим більш повноцінно та ефективно.

При впровадженні доктринальних засад та практик медичного забезпечення країн-членів НАТО у віт- чизняну систему охорони здоров'я необхідно врахувати національні особливості усіх сфер суспільного життя.

Системні зміни у сфері охорони здоров'я необхідні, але еволюційні, адекватні до соціально-економічних умов, функціонально сприятливі в дієвості, науково-обгрунтовані з урахуванням кращих міжнародних практик та власного історичного досвіду.

Ці та деякі інші заходи забезпечать еволюційний розвиток державної системи медичного захисту населення у загальній системі національної безпеки України.

\section{СПИСОК ВИКОРИСТАНИХ ДЖЕРЕЛ}

1. Афонін Е. А. Велика розтока (глобальні проблеми сучасності: соціально-історичний аналіз) / Е. А. Афонін, О. М. Бандурка, А. Ю. Мартинов. - К.: ПАРАПАН, 2002. $352 \mathrm{c}$.

2. Афонін Е. А., Суший О. В. Закономірності та особливості української трансформації / Е. А. Афонін, О. В. Суший // Стратегічна панорама. - 2015. - № 1. - С. 94-108.

3. Становление Вооруженных Сил Украины: социальные и социально-психологические проблемы : монография / Э. А. Афонин; НАГУ при Президенте Украины. - К. : НТЦ “Психея”, 2014. - С. 11.

4. Суший E. B. Архетипика как новое научное направление междисциплинарных исследований проблем государственного управления / Е. В. Суший, Э. А. Афонин // Гос. упр. в XXI веке: традиции и инновации: 9-я Междунар. конф., (25-27 мая 2011 г.). - М.: Издво Москов. ун-та, 2011. - Ч. 3. C. 111-122. 
5. Суший О. В. Українське диво О. В. Суший // Укр. соціум : наук.-практ. журн. - 2018. - № 4 (67). - C. 162-165.

6. Теоретичні засади соціальної архетипіки / О. В. Суший // Публічне урядування. - 2016. - № 3. С. 168-180.

7. Волянський П. Б. Комплексний аналіз потреби в медичному захисті населення від наслідків надзвичайних ситуацій // Держ. управління: удосконалення та розвиток. 2015. - № 3.

8. Гур'єв С. О., Юрченко В. Д., Близнюк М. Д. Нормативно-правові основи реорганізації системи реагування та ліквідації медико-санітарних наслідків надзвичайних ситуацій на територіальному рівні: довід. посіб. МОЗ України, УНПЦ ЕМД та МК, КМАПО ім. П. Л. Шупика. - К., 2013. - 84 c.

9. Медичне забезпечення антитерористичної операції: Воєнномедична доктрина України як інструмент формування єдиного медичного простору / В. О. Жаховський // Україна. Здоров'я нації. 2015. - Вип. № 1 (33). - С. 7 14.

10. Civil-Military Operation. Join publication 3-57. 2013.

11. Шостак Л. Й. Механізми забезпечення взаємодії суб'єктів державної системи ліквідації медико-санітарних наслідків надзвичайних ситуацій: дис. канд. наук з держ. упр.: 25.00.02 / ОРІДУ НАДУ. - Одеса, 2014. - 133 c.

12. Закон України "Кодекс цивільного захисту України” від 02.10.2012 р. № 5403-VI [Електронний ресурс]. Режим доступу : www.zakon.rada.gov. ua/laws/show/5403-17

13. Закон України "Про екстрену медичну допомогу” № 5081-VI від 05.07.2012 p. [Електронний pe- cурс]. - Режим доступу: http:// zakon.rada.gov.ua/laws/show/5081-17

14. Указ Президента України "Про рішення Ради національної безпеки і оборони України від 6 травня 2015 р. "Про Стратегію національної безпеки України” від 26.05.2015 р. № 287.

\section{REFERENCES}

1. Afonin E. A., Bandurka O. M., Martynov A. Yu. (2002). Velyka roztoka (hlobalni problemy suchasnosti: sotsialno-istorychnyi analiz) [Velyka roztoka (global problems of the present: socio-historical analysis)]. Kyiv: PARAPAN [in Ukrainian].

2. Afonin E. A., Sushyi O. V. (2015). Zakonomirnosti ta osoblyvosti ukrainskoi transformatsii [Laws and Peculiarities of Ukrainian Transformation]. Stratehichna panorama - Strategic Panorama, 1, 94-108 [in Ukrainian].

3. Afonin E. A. (2014). Stanovlenie Vooruzhennykh Sil Ukrainy: sotsial'nye i sotsial'no-psikhologicheskie problemy [Formation of the Armed Forces of Ukraine: social and sociopsychological problems]. Kyiv: NTTs "Psikheya" [in Russian].

4. Sushiy E. V. (2011). Arkhetipika kak novoe nauchnoe napravlenie mezhdistsiplinarnykh issledovaniy problem gosudarstvennogo upravleniya [Archetypical as a new scientific direction of interdisciplinary research of public administration problems]. Gos. upr. v XXI veke: traditsii i innovatsii - State administration in the XXI century: traditions and innovations: $9^{\text {th }}$ International conference. (Vols. 3). (p. 111122). Moscow: Izd-tvo Mosk. un-ta [in Russian].

5. Sushyi O. V. (2018). Ukrainske dyvo [Ukrainian miracle]. Ukrainskyi sotsium - Ukrainian Society, 4 (67), 162-165 [in Ukrainian]. 
6. Sushyi O. V. (2016). Teoretychni zasady sotsialnoi arkhetypiky [Theoretical foundations of social archetype]. Publichne uriaduvannia Public administration, 3, 168-180 [in Ukrainian].

7. Volianskyi P. B. (2015). Kompleksnyi analiz potreby $\mathrm{v}$ medychnomu zakhysti naselennia vid naslidkiv nadzvychainykh sytuatsii [Comprehensive analysis of the need for medical protection of the population from the emergencies consequences]. Derzhavne upravlinnia: udoskonalennia ta rozvytok - Public Administration: Improvement and Development, 3. Retrieved from http://www.dy. nayka.com.ua/?op $=1 \& z=818$ [in Ukrainian].

8. Huriev S. O., Yurchenko V. D., Blyzniuk M. D. (2013). Normatyvno-pravovi osnovy reorhanizatsii systemy reahuvannia ta likvidatsii medykosanitarnykh naslidkiv nadzvychainykh sytuatsii na terytorialnomu rivni. (Dovidkovyi posibnyk) [Regulatory bases of reorganization of the system of response and liquidation of health consequences of emergency situations at the territorial level. (Reference Guide)]. Kyiv: MOZ Ukrainy, UNPTs EMD ta MK, KMAPO im. P. L. Shupyka [in Ukrainian].

9. Zhakhovskyi V. O. (2015). Medychne zabezpechennia antyterorystychnoi operatsii: Voienno-medychna doktryna Ukrainy yak instrument formuvannia yedynoho medychnoho prostoru [Medical support of the antiterrorist operation: Military medical doctrine of Ukraine as an instrument for the formation of a single medical space]. Ukraina. Zdorovia natsii Ukraine. The health of the nation, 1 (33), 7-14 [in Ukrainian].
10. Civil-Military Operation. Joint publication 3-57. (2013). www.jcs.mil. Retrieved from https://www.jcs.mil/ Portals/36/Documents/Doctrine/ pubs/jp3_57.pdf [in English].

11. Shostak $\bar{L}$. Y. (2014). Mekhanizmy zabezpechennia vzaiemodii subiektiv derzhavnoi systemy likvidatsii medyko-sanitarnykh naslidkiv nadzvychainykh sytuatsii [Mechanisms for ensuring the interaction of subjects of the state system of medical and sanitary consequences of emergency situations liquidation]. Odesa: ORIDU NADU [in Ukrainian].

12. Zakon Ukrainy "Kodeks tsyvilnoho zakhystu Ukrainy" : vid 02.10.2012, № 5403-VI [The Law of Ukraine "Code of Civil Protection of Ukraine": from 02.10.2012, № 5403-VI]. (n.d.). zakon. rada.gov.ua. Retrieved from www.zakon.rada.gov.ua/laws/show/5403-17. [in Ukrainian].

13. Zakon Ukrainy "Pro ekstrenu medychnu dopomohu” : vid 05.07.2012 № 5081-VI [Law of Ukraine "On Emergency Medical Aid" from 05.07.2012, № 5081-VI]. (n.d.). zakon. rada.gov.ua. Retrieved from http://zakon.rada.gov.ua/laws/show/5081-17 [in Ukrainian].

14. Ukaz Prezydenta Ukrainy "Pro rishennia Rady natsionalnoi bezpeky i oborony Ukrainy vid 6 travnia 2015 roku "Pro Stratehiiu natsionalnoi bezpeky Ukrainy” : vid 26.05.2015, № 287 [Decree of the President of Ukraine "On the decision of the National Security and Defense Council of Ukraine" from May 6, 2015 "On the Strategy of National Security of Ukraine" from 26.05.2015, № 287]. (n.d.). zakon.rada. gov.ua. Retrieved from https://zakon. rada.gov.ua/laws/show/287/2015 [in Ukrainian]. 